\title{
Penerapan Metode Brain Storming Dalam Meningkatkan Hasil Belajar Matematika Siswa Kelas XI Akomodasi Perkantoran di Sekolah Menengah Kejuruan
}

\author{
Sirajuddin $^{1}$, Rodi Kurniawan ${ }^{2}$ \\ ${ }^{1,2}$ Pendidikan Matematika, Universitas Muhammadiyah Mataram, Indonesia \\ ${ }^{1}$ sirajuddin.ekhy@gmail.com, ${ }^{2}$ rodikurniawan@gmail.com
}

\section{INFO ARTIKEL}

Riwayat Artikel:

Diterima: 03-08-2018

Disetujui: $13-10-2018$

\section{Kata Kunci:}

Brain Storming, Hasil Belajar

\begin{abstract}
ABSTRAK
Abstrak: Tujuan penelitian adalah dengan menerapkan Metode Brain Stirming untuk meningkatkan hasil belajar siswa. Jenis penelitian adalah Penelitian Tindakan Kelas, subyek dari penelitian ini adalah siswa kelas XI Administrasi Perkantoran sebanyak 31 siswa. Instrumen penelitian yang digunakan adalah tes evaluasi hasil belajar dan lembar observasi. Berdasarkan hasil analisa data diperoleh hasil ketuntasan klasikal siswa pada siklus I sebesar $64,5 \%$ sedangkan pada siklus II diperoleh hasil ketuntasan klasikal siswa sebesar 90,3\%. Dengan demikian dapat disimpulkan bahwa penerapan Metode Brain Storming dapat meningkatkan hasil belajar matematika siswa pada materi Barisan dan Deret.
\end{abstract}

\begin{abstract}
The purpose of the study is to apply the Brain Stirming Method to improve student learning outcomes. This type of research is Classroom Action Research, the subject of this study were students of class XI Office Administration as many as 31 students. The research instrument used was the learning outcome evaluation test and observation sheet. Based on the results of data analysis, the results of classical completeness of students in the first cycle were $64.5 \%$, while in the second cycle the results of classical completeness of students were $90.3 \%$. Thus it can be concluded that the application of the Brain Storming Method can improve students' mathematics learning outcomes in the Sequence and Series material.
\end{abstract}

\section{A. LATAR BELAKANG}

Salah satu pertanda bahwa seseorang itu telah belajar adalah adanya perubahan tingkah laku pada diri orang itu yang mungkin disebabkan oleh terjadinya perubahan pada tingkat pengetahuan, keterampilan atau sikapnya. Dalam keseluruhan proses pendidikan disekolah, kegiatan belajar merupakan kegiatan yang paling pokok. Ini berarti bahwa berhasil tidaknya siswa untuk mencapai tujuan pendidikan yang telah ditetapkan banyak bergantung pada bagaimana proses belajar mengajar dikelas. Pendidikan merupakan interaksi antara pendidik dengan siswa dalam upaya membantu siswa menguasai tujuan-tujuan pendidikan yaitu meningkatkan kecerdasan dan keterampilan (Ahmadi, 2003: 208). Namun keadaan di lapangan belumlah sesuai dengan yang diharapkan. Hasil study oleh direktorat (2000) menyebutkan bahwa meski adanya peningkatan mutu pendidikan yang cukup menggembirakan, namun pembelajaran dan pemahaman siswa SMA/SMK (pada beberapa mata pelajaran termasuk matematika) menunjukkan hasil yang kurang memuaskan. Cara pembelajaran disekolah menengah cendrung abstrak, monoton dan kurang terkait dengan kehidupan sehari-hari siswa. Guru hanya menggunakan metode ceramah yaitu metode yang bisa dikatakan metode tradisional, karena sejak dulu metode ini telah dipergunakan sebagai alat komunikasi lisan antara guru dengan murid dan dalam penerapannya pada proses belajarmengajar lebih berpusat pada guru, siswa hanya mendengarkan, menulis dan menghafal materi yang diajarkan sehingga konsep-konsep pembelajaran kurang bisa atau sulit dipahami.Sementara itu kebanyakan guru dalam mengajar masih kurang memperhatikan kemampuan berpikir siswa, atau dengan kata lain tidak melakukan pengajaran bermakna, Metode yang digunakan kurang bervariasi dan sebagai akibatnya motivasi belajar siswa menjadi sulit untuk ditumbuhkan.

Keanekaragaman metode pembelajaran merupakan upaya alternatif dalam penerapan metode pembelajaran matematika yang hendak 
diterapkan yang selaras dengan tingkat perkembangan kognitif, afektif dan psikomotorik peserta didik. Ini artinya bahwa tidak ada metode pembelajaran yang paling baik atau metode pembelajaran yang satu lebih baik dari metode pembelajaran yang lain. Baik tidaknya suatu model pembelajaran atau pemilihan suatu metode pembelajaran akan bergantung pada tujuan pembelajaran, kesesuaian dengan materi yang hendak disampaikan, perkembangan peserta didik, dan juga kemampuan guru dalam mengelola dan memberdayakan sumber daya belajar yang ada.

Sekolah Menengah Kejuruan Negeri 4 Mataram sebagai sekolah yang telah banyak didukung oleh berbagai sarana antara lain seperti : LKS, Buku Paket, Perpustakaan, Lab Multimedia dan lain-lain untuk menunjang proses belajar mengajar yang baik masih memerlukan metode pembelajaran yang sesuai dengan kondisi siswa. Berdasarkan observasi pada tahap awal di SMKN 4 Mataram, penerapan metode dalam setiap pembelajaran belum mampu bervariasi dan masih mengacu pada paradigma lama seperti mengajar dengan metode ceramah. Selain itu metode-metode yang disajikan kepada siswa masih didominasi oleh berbagai kegiatan yang hanya berpatok pada kegiatan guru dalam mengajar dan para siswa hanya menerima materi pelajaran tanpa banyak membuat alternatif-alternatif lain dalam belajar. Adanya hal-hal tersebut membuat siswa merasa bosan dan jenuh dalam setiap kegiatan belajar khususnya pada mata pelajaran Matematika. Hasil belajar yang diperoleh oleh sebagian siswa adalah rendah dan menyebabkan tujuan pembelajaran tidak dapat tercapai semaksimal mungkin. Salah satu penyebabnya adalah metode pembelajaran yang konvensional, sejalan dengan hal tersebut maka guru mata Pelajaran Matematika dituntut agar mampu menyiasati dan mencermati keadaan tersebut dengan menerapkan metode pembelajaran yang tepat, sesuai dengan materi yang disampaikan. Sesuai dengan pendapat Roestiyah dalam Djamarah, Guru memiliki strategi agar anak didik dapat belajar secara afektif dan efesien, mengena pada tujuan yang diharapkan. Salah satu langkah untuk memiliki strategi itu adalah harus menguasai teknik-teknik penyajian atau biasanya disebut metode mengajar(Djamarah dan Aswan, 2006:74). Dengan melihat permasalahan di atas, maka perlu diupayakan suatu strategi pembelajaran dengan melakukan tindakan yang dapat melibatkan siswa untuk lebih aktif dalam proses pembelajaran. Pembelajaran yang sesuai dengan keadaan tersebut adalah pembelajaran dengan metode Brain Storming.

Brain Storming merupakan cara yang dilakukan oleh guru didalam kelas, dengan melontarkan suatu masalah yang mampu merangsang pikiran siswa, sehingga siswa dikelas menjawab atau menyatakan pendapat dan guru menampung semua pendapat siswa dan dari pendapat-pendapat siswa tersebut memungkinkan masalah tersebut berkembang menjadi masalah baru. Tugas guru disini adalah memberikan masalah yang mampu merangsang pikiran siswa, sehingga siswa menanggapi permasalahan yang diberikan oleh guru, dan guru tidak boleh memberikan komentar atau menyalahkan pendapat siswa, guru hanya menyimpulkan pendapat-pendapat dari siswa (Roestiyah, 2012:73-74). Metode Brain Storming diharapkan mampu merangsang siswa untuk selalu siap dan aktif berfikir dalam menyatakan pendapat yang berhubungan dengan masalah yang diberikan oleh guru untuk berfikir dengan cepat dan tersusun logis. Kesadaran perlunya metode Brain Storming dalam pembelajaran didasarkan adanya unsur kemauan untuk merangsang siswa mengeluarkan ide-ide, siap dan aktif berfikir dalam menyatakan pendapat yang berhubungan dengan masalah yang diberikan oleh guru, melatih siswa berfikir dengan cepat dan tersusun logis, meningkatkan partisipasi dalam menerima pelajaran. Dengan adanya penerapan metode brain storming siswa diharapkan lebih aktif dalam menyelesaikan soal terkait dalam pembelajaran matematika pada materibarisan dan deret, maupun dalam mengeluarkan pendapat selama diskusi yang diberikan oleh guru, agar proses pembelajaran berlangsung dengan baik dan menghasilkan suatu peningkatan dalam hasil belajar.

\section{B. METODE PENELITIAN}

\section{Seting Penelitian}

Penelitian ini dilakukan dengan menggunakan Penelitian Tindakan Kelas (PTK). Penelitian tindakan kelas adalah penelitian yang dilakukan oleh guru dikelasnya sendiri melalui refleksi diri dengan tujuan untuk memperbaiki kinerja siswa sehingga hasil belajar siswa meningkat (Aqib Zainal, dkk, 2008:3). Penelitian ini menggunakan metode Brain Storming karena metode ini akan membawa siswa untuk lebih aktif, sebab metode Brain Storming membantu siswa untuk mengeluarkan ide atau gagasan yang dimilikinya.

\section{Rencana Tindakan}

Rencana tindakan merupakan penyajian data untuk membangun suatu program didalam rangka mengimplementasikan suatu agenda penelitian yang sedang berjalan untuk menyelidiki praktik kegiatan(Ghoni.D, 2008:20). Rencana tindakan terdiri dari beberapa siklus yang diantaranya siklus tersebut mempunyai empat tahapan seperti pada gambar dibawah ini: 


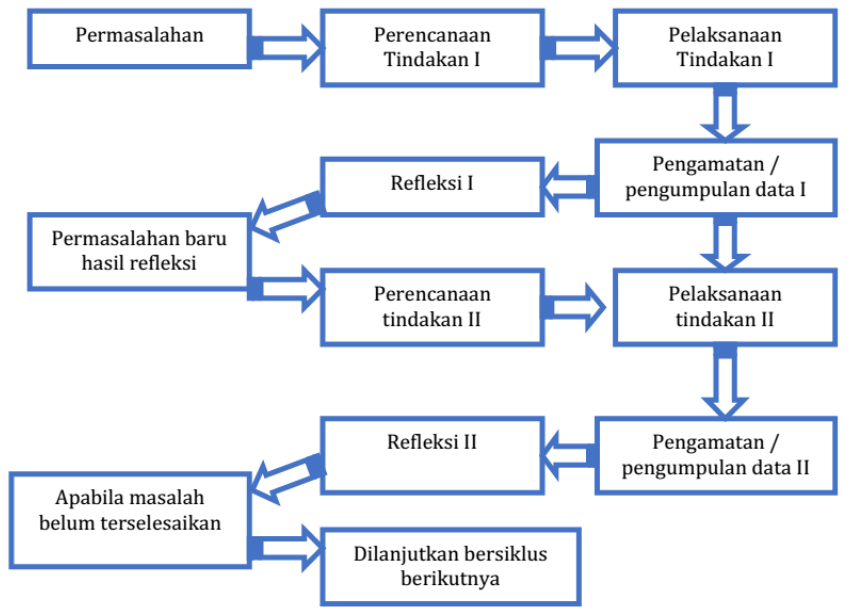

Gambar 1. Alur PTK (Suharsimi, 2007:16)

a. Tahap Perencanaan

Pada tahap ini kegiaatan yang akan dilakukan dalam siklus pertama ini adalah peneliti dengan guru bidang studi matematika mempersiapkan hal-hal sebagai berikut:

1) Menyiapkan skenario pembelajaran (SP)atau Rencana pembelajaran(RPP)

2) Menyiapkan proses blajar mengajar.

3) Menyusun tes hasil belajar siswa dalam bentuk essay untuk mengetahui hasil belajar siswa

4) Menyiapkan lembar kerja siswa(LKS)dan soal-soal latihan

b. Pelaksanaan Tindakan

Pada tahap ini merupakan tahap pelaksanaan dari rencana pembelajaran atau skenario pembelajaran yang telah disiapkan, memberikan permasalahan yang akan dibahas, menganalisis hasil evaluasi, dan proses yang dilakukan terbagi dalam tahap kegiatan inti dan penutup

c. Pengamatan

Tahap ini sebenarya berjalan bersama dengan saat pelaksanaan tindakan. Pada tahap ini dilakukan observasi terhadap penggunaan metode Brain Storming dalam meningkatkan hasil belajar, dimana peneliti dan siswa yang akan di observasi oleh guru bidang studi dalam kegiatan belajar mengajar sehingga diketahui (RPP) yang telah di buat.

d. Refleksi

Pada tahap ini peneliti mengumpulkan hasil yang di dapatkan pada tahap observasi untuk di analisis, kemudian peneliti menganalisis ketuntasan hasil belajar siswa pada pada siklus pertama .Jika terdapat masalah pada siklus pertama seperti banyak siswa yang tidak tuntas, dan peneliti sebagai pengajar masih terdapat padanya kekurangankekurangan pada proses belajarmengajar, maka berlangsung dari hasil proses refleksi ini sebagai bahan untuk melakukan refisi dan perbaikan pada perencana dan proses pada siklus berikutnya tentang meliputi kegiatan :perencanaan ulang, kegiatan ulang, dan pengamatan ulang sampai permasalahan dapat teratasi.

\section{Jenis Instrumen Dan Cara Penggunaannya}

Instrumen adalah alat pada waktu peneliti menggunakan suatu metode. Jadi, instrmen penelitian merupakan alat bantu yang di gunakan oleh peneliti untuk mengumpulkan data-data atau informasi dalam penelitian (Sugiono, 2006:148). Dari uraian ini, maka instrumen yang digunakan sebagai berikut :

a. Tes hasil belajar

Tes merupakan cara untuk mengadakan penilaian yang bentuk suatu tugas atau serangkaian tugas yang harus dikerjakan oleh anak atau sekelompok anak sehingga menghasilkan suatu nilai tentang tingkah laku atau hasil tersebut, yang dapat dibandingkan dengan nilai yang dicapai oleh anak-anak lain atau nilai standar ditetapkan (Dimyanti dkk, 2006:257-258). Teknik tes sebagai metode pengumpulan data dalam penelitian ini akan dipergunakan untuk mendapatkan data hasil siswa dalam penerapan metode Brain Storming.

b. Observasi

Observasi diartikan sebagai pengamatan dan pencatatan secara sistimatis terhadap gejala yang tampak pada objek penelitian. Observasi dilakukan untuk memperoleh gambaran langsung tentang proses pembelajaran dengan menggunakan metode Brain Storming dalam meningkatkan hasil blajar siswa. Melalui hal itu diketahui aktivitas siswa dan guru selama proses belajar mengajar berlangsung. Dalam pelaksanaan observasi, peneliti secara langsung ke lokasi peneliti untuk mengobservasi penggunaan pembelajaran dengan menggunakan metode Brain Storming dalam meningkatkan hasil balajar siswa kelas XI APK 1 Semester I di SMKN 4 Mataram pada pembelajaran matematika materiBarisan dan Deret. Cara pengambilan data dengan observasi yaitu guru bidang studi mengamati proses kegiatan belajar mengajar dan menggunakan lembar observasi peneliti dan lembar observasi siswa. Data yang akan di kumpulkan dengan observasi adalah data tentang proses pembelajaran matematika khususnya pada sub materibarisan dan deret di terapkannya metode Brain Storming.

c. Dokumentasi

Dokumentasi yakni, mencari data mengenai hal-hal atau variabel yang berupa catatan, transkrip, buku, surat kabar, majalah, prasasti, 
notulen rapat, lengger, agenda dan sebagainya. Dalam penelitian ini peneliti menggunakan Dokumentasi karena banyak dibutuhkan dokumen dari subjek yang diteliti, seperti data tentang sejarah berdirinya SMKN 4 Mataram, daftar nama siswa, daftar nilai hasil evaluasi siswa, data tentang keadaan guru, keadaan siswa dalam tahap belajar, keadaan siswa waktu belajar kelompok, keadaan siswa waktu mengeluarkan pendapat pada proses belajar, keadaan siswa waktu evaluasi, sarana dan prasarana serta struktur organisasi sekolah.Hai ini dapat dilihat diakhir lampiran.

\section{Pelaksanaan Tindakan}

Dalam Pelaksanaan tindakan ini guru bersama peneliti melaksanakan skenario pembelajaran dengan penerapan metode brain storming. Metode Brain Storming merupakan salah satu teknik untuk memperkirakan sejauh mana pengetahuan (penguasaan materi) yang telah dimiliki oleh siswa, cara untuk mendapatkan banyak ide dari sekelompok manusia dalam waktu yang sangat singkat (Roestiyah, 2012:74). Adapun pelaksanaan tindakan dilakukan sebagaimana yang telah disebutkan dalam rencana tindakan bahwa penelitian tindakan kelas ini dilakukan dalam beberapa siklus. Sitiap siklus terdiri dari beberapa tahapan yaitu perencanaan (planning), pelaksanaan tindakan (action), observasi (observation) atau evaluasi dan refleksi (reflection).

Dalam pelaksanaan metode ini tugas guru adalah memberikan masalah atau penjelasan yang mampu merangsang pikiran siswa untuk menjawab soal-soal, sehingga siswa menanggapi semua isi materi, mengemukakan pendapat, komentar, bertanya atau mengemukakan masalah baru, mereka belajar dan melatih merumuskan pendapatnya dalam menjawab pernyataan yang di berikan oleh guru dengan bahasa dan kalimat yang baik. Siswa yang kurang aktif berani mengemukakan pendapatnya atau berani tampil untuk menjawab soal sesuai dengan pembahasan yang di berikan oleh guru. Guru tidak boleh mengomentari bahwa pendapat siswa itu benar/salah ;juga tidak perlu di simpulkan, guru hanya menampung semua pernyataan pendapat siswa, sehingga semua siswa di dalam kelas mendapat giliran, guru tidak perlu komentar atau evaluasi selama siswa masih diberi kesempatan untuk mengeluarkan ide-ide baru (Roestiyah, 2012:74).

Langkah-langkah guru dalam menggunakan metode Brain Stormingdi kelas XI APK 1 Semester 1 SMKN 4 Mataram sebagai berikut:

a. Guru memberikan penjelasan materi kepada siswa terkait pembahasan barisan dan deret

b. Siswa dibagi menjadi beberapa kelompok yang masing-masing anggotanya 5 orang. c. Guru melontarkan masalah pada siswa berupa pertayaan yang berbentuk soal-soal essay yang diberikan langsung kepada masing-masing kelompok

d. Masing-masing kelompok mengemukakan pendapat atau komentar, sedangkan guru mencatatnya dipapan tulis tanpa mengadakan perubahan

e. Guru dan siswa bersama-sama mengevaluasi setiap gagasan yang telah dikemukakan tadi

f. Guru bersama peneliti melakukan evaluasi dengan memberikan soal-soal berbentuk essay.

\section{Cara Pengamatan (Monitoring)}

Penelitian ini dilakukan di SMKN 4 Mataram yang dipimpin oleh guru matematika. Peneliti melakukan pengamatan langsung ke lokasi penelitian dan mengadakan wawancara langsung dengan guru mata pelajaran matematika, untuk mendapatkan data-data yang akurat dan bagaimana proses belajar mengajar berlangsung.

\section{Analisis Data dan Indikator Penelitian}

Analisis data yang diperoleh dari hasil observasi dianalisis menggunakan kriteria sesuai Tabel 1 dan Tabel 2 berikut.

TABEL 1

KRITERIA PENILIAN DATA AKTIVITAS GURU

\begin{tabular}{cl}
\hline Nilai & \multicolumn{1}{c}{ Kategori } \\
\hline $18,75 \leq \mathrm{M}$ & Sangat aktif \\
\hline $14,58 \leq \mathrm{M} \leq 18,75$ & Aktif \\
\hline $10,42 \leq \mathrm{M}<14,58$ & Cukup aktif \\
\hline $6,25 \leq \mathrm{M}<10,42$ & Kurang aktif \\
\hline $\mathrm{M}<6,25$ & Sangat kurang aktif \\
\hline
\end{tabular}

TABEL 2

KRITERIA PENILAIAN DATA AKTIVITAS BELAJAR SISWA

\begin{tabular}{cl}
\hline Nilai & \multicolumn{1}{c}{ Kategori } \\
\hline $22,5 \leq \mathrm{M}$ & Sangat aktif \\
\hline $17,5 \leq \mathrm{M} \leq 22,5$ & Aktif \\
\hline $12,5 \leq \mathrm{M}<17,5$ & Cukup aktif \\
\hline $7,5 \leq \mathrm{M}<12,5$ & Kurang aktif \\
\hline $\mathrm{M}<7,5$ & Sangat kurang aktif \\
\hline
\end{tabular}

Tes hasil belajar disini dan dianalisis secara deskriptif statistik dengan langkah-langkah yaitu dengan mencari ketuntasan belajar, utuk mengetahui ketuntasan belajar siswa digunakan keriteria sebagai berikut :

a. Ketuntasan individu yaitu setiap siswa dalam proses belajar mengajar dikatakan tuntas secara individu terhadap materi pelajaran yang diberikan jika siswa mampu memperoleh nilai $\geq 75$.

b. Ketuntasan klasikal. Ketuntasan klasikal dikatakan telah dicapai apabila target pencapaian ideal $\geq 85 \%$ dari jumlah siswa dalam kelas. Hal ini dapat dihitung dengan rumus sebagai berikut : 
$\mathrm{KK}=\frac{X}{Z} \times 100 \%$

Dimana $\mathrm{KK}=$ Ketuntasan klasikal, $\mathrm{X}=$ Jumlah siswa yang memperoleh nilai $\geq 75$, dan $Z=$ Banyaknya siswa

\section{Indikator Penelitian}

Yang menjadi indikator keberhasilan pada penelitian ini dapat dilihat dari peningkatkan hasil belajar siswa kelas XI APK 1 di SMKN 4 Mataram. Hasil belajar dikatakan meningkat apabila nilai ratarata dari siklus ke siklus mengalami peningkatan atau minimal $85 \%$ setelah diterapkannya Metode Brain Storming.

\section{HASIL DAN PEMBAHASAN}

\section{Hasil Observasi Aktifitas Siswa Siklus I}

Untuk mengetahui hasil observasi aktifitas belajar siswa yang dilakukan adalah mengamati prilaku siswa pada saat diskusi dan mengeluarkan pendapat untuk menyelesaiakan tugas, semua aktifitas yang nampak dicatat dalam lembar observasi.

Data lengkap mengenai aktivitas belajar siswa selama proses pembelajaran dengan menerapkan metode brain storming pada siklus I dapat dilihat pada lampiran 3.2 dan 3.6 tentang aktivitas belajar siswa siklus I pertemuan pertama dan pertemuan kedua. Nilai Mean Ideal (MI) adalah13 dan Standar Deviasi Ideal (SDI) adalah 6,5 sehingga penggolongan aktivitas belajar siswa dapat dilihat.

Berdasarkan hasil yang ditemukan dari siklus I pada pertemuan pertama yang rata-rata 21 dan nilainya sesuai dengan nilai yang berada di tabel, maka katgori yang terkait dengan nilainya termasuk dengan kategori aktif. Sedangkan untuk pertemuan kedua nilai rata-ratanya yaitu 21 , dengan nilainya sesuai dengan tabel, maka nilai tersebut termasuk kategori Aktif.

\section{Hasil Observasi Aktivitas Guru Siklus I}

Untuk mengetahui hasil observasi aktifitas guru yang dilakukan adalah mengamati cara guru menyampaikan materi sesuai dengan penerapan metode yang dilakukan baik dalam pemberian soal, membagi kelompok maupun menyimpulkan materi,semua aktifitas yang nampak dicatat dalam lembar observasi.

Data lengkap mengenai aktifitas guru selama proses pembelajaran dengan menggunakan matede brain storming pada siklus I dapat dilihat pada lampiran 3.2 dan 3.5 pada pertemuan pertama dan kedua. Berdasarkan analisa data diperoleh jumlah seluruh skor total aktifitas guru yang nampak sebanyak 15, dengan banyaknya item 20 yaitu banyaknya deskriptor, untuk mengetahui hasilnya cukup dengan melihat berapa jumlah sekor yang di peroleh pada lembar observasi aktifitas guru dan tentukan katagori yang di dapat dengan mengacu pada pedomen pensekoran aktifitas guru pada tabel 2. Hasil total yang di peroleh 15 yang terdapat pada interval $14,58 \leq \mathrm{M} \leq 18,75$ dengan katagori aktif. Yang menjadi kekurangan-kekurangan yang muncul pada siklus I pertemuan pertama adalah :

a. Guru tidak menyampaikan tujuan pembelajaran mengakibatkan siswa masih belum tau apa mamfaat yang diterima setelah belajar materi yang disamapaikan guru

b. Guru tidak membuat kelompok-kelompok sehingga proses pembelajaran masih terlihat biasa

c. Guru tidak mencatat kesulitan-kesulitan yang dialami siswa selam peroses pembelajran berlangsung

d. Guru tidak meminta siswa untuk menyimpulkan materi yang telah disampaikan.

Kemudian pada pertemuan ke-2 bahwa jumlah seluruh skor total aktifitas guru yang nampak sebanyak 18, dengan banyaknya item 20 yaitu banyaknya deskriptor, untuk mengetahui hasilnya cukup dengan melihat berapa jumlah sekor yang di peroleh pada lembar observasi aktifitas guru dan tentukan katagori yang di dapat dengan mengacu pada pedomen pensekoran aktifitas guru pada tabel 2. Hasil total yang di peroleh 18 yang terdapat pada interval $14,58 \leq \mathrm{M} \leq 18,75$ dengan katagori aktif. Yang menjadi kekurangan-kekurangan yang muncul pada siklus I pertemuan pertama adalah:

a. Guru tidak mencatat kesulitan-kesulitan yang dialami siswa selama proses pembelajaran berlangsung

$b$. Guru tidak meminta sisa menyimpulkan apa yang telah disampaikan guru.

Setelah melakukan kegiatan pembelajaran dengan menggunakan penerapan metode brain storming dengan pendekatan sebanyak dua kali pertemuan perminggu, maka pertemuan selanjutnya guru memberikan evaluasi kepada siswa. Evalusi berlangsung selama dua jam pelajaran.Bentuk soal evaluasi adalah essay sebanyak 5 soal untuk dikerjakan secara individu. Masing-masing siswa mendapatkan satu lembar soal. Jawaban siswa kemudian diperiksa dengan skor maksimal 100 jika semua jawaban siswa benar dan skor 0 jika siswa tidak menjawab sama sekali. Melalui hasil evaluasi belajar nilai rata-rata siswa dan ketuntasan belajar siswa dapat dilihat pada table berikut:

TABEL 3

HASIL EVALUASI BELAJAR SISWA KELAS XI APK SIKLUS I

\begin{tabular}{clc}
\hline No & \multicolumn{1}{c}{ Aspek yang diukur } & Keterangan \\
\hline 1. & Jumlah siswa yang ikut evaluasi & 31 \\
\hline 2. & Jumlah siswa yang tuntas & 20 \\
(siswa yang mencapai nilai 60 & \\
atau lebih) & \\
\hline
\end{tabular}




\begin{tabular}{llc}
\hline 3. & $\begin{array}{l}\text { Jumlah siswa yang tidak tuntas } \\
\text { (siswa yang nilainya kurang } \\
\text { dari 60 ) }\end{array}$ & 11 \\
\hline 4. & Persentase ketuntasan & $64,5 \%$ \\
\hline 5. & Jumlah skor keseluruhan & 2595 \\
\hline 6. & Nilai rata-rata siswa & 83,709 \\
\hline 7. & Kategori & Belum \\
& & Tuntas \\
\hline
\end{tabular}

Dari Tabel di atas dijelaskan bahwa jumlah siswa sebanyak 31 orang, jumlah siswa yang mengikuti evaluasi sebanyak 31, jumlah siswa yang tuntas sebanyak 20 sedangkan yang tidak tuntas sebanyak 11 yaitu nilainya yang kurang dari 75 . Untuk mengetahui persentase ketuntasan jumlah siswa yaitu 20 dibagi dengan jumlah seluruh siswa yaitu 31 dengan memperoleh hasil $64,5 \%$. Untuk mengetahui jumlah skor keseluruhan hasil seluruh masing-masing siswa dijumlahkan dengan jumlah ketercapaian 2595, sedangkan untuk memperoleh hasil nilai rata-rata siswa jumlah nilai seluruh siswa dibagi dengan jumlah siswa dengan memperoleh hasil 83,709.

Berdasarkan hasil analisis pada tabel di atas terlihat bahwa ketuntasan belajar secara klasikal belum mencapai standar minimal $85 \%$ dan penggolongan aktifitas belajar siswa pada pertemuan petama dengan katogori aktif,dan pertemuan kedua dengan kategori aktif. Hasil analisis secara rinci tentang hasil evaluasi belajar siswa siklus I dapat terlahat pada lampiran 3.10. Dari tabel diatas dapat juga dijelaskan bahwa ada 7 orang siswa yang tidak tuntas secara individu pada siklus I ini. Pada pertemuan siklus berikutnya akan diberikan bimbingan dan perhatian khusus dikelas ketika proses belajar mengajar berlangsung di samping itu juga guru memberikan upaya dalam mengendalikan kendala yang dihadapi atau penyebab lain yang dialami oleh 11 orang siswa tersebut. Karena penelitian pada siklusI belum mencapai ketuntasan belajar klasikal, maka peneliti merencanakan tindakan perbaikan pada siklus II.

Persantase ketuntasan belajar mengajar $64,5 \%$ ini menunjukkan bahwa ketuntasan dilihat dari hasil evaluasi pada siklus I masih belum mencapai hasil yang diharapkan.Adapun kekurangan-kakurangan yang ditemukan pada siklus ini akan di perbaiki pada siklus kedua di antaranya:

a. Guru masih kurang dalam memberikan motivasi kepada siswa yang kurang aktif untuk berani mengeluarkan pendapat dan berani maju untuk mengerjakan tugas di depan kelas

b. Guru masih terfokus pada kelompokkelompok tertentu dan kelompok yang lain masih bersifat kurang aktif' c. Pada saat mengarjakan LKS masih banyak siswa -siswi yang belum begitu paham dengan materi yang telah di ajarkan

d. Antusias siswa dalam pendekatan masih kurang karena masih banyak siswa yang terpengaruh situasi dalam kelas.

\section{Hasil Observasi Aktifitas Siswa Siklus II}

Berdasarkan hasil analisa data diketahui bahwa jumlah indikator adalah 25, dan sekor total yang diperoleh pada pertemuan pertama, kedua dan ketiga sebanyak 24, sehingga katgori yang terkait dengan nilai tersebut termasuk dengan kategori Sangat Aktif.

\section{Hasil Observasi Aktivitas Guru Siklus II}

Berdasarkan hasil analisa data dapat diketahui jumlah skor total yang didapatkan oleh guru yaitu skor totalnya 19 , dari 20 aitem, yang terdapat pada interval $18,75 \leq \mathrm{M}$ kategori sangat aktif yang lebih meningkat di bandingkan dengan aktifitas guru pada siklus I. Namun masih ada kekurangannya yaitu: Guru tidak mencatat kesulitan-kesulitan yang diterima siswa pada saat proses pembelajaran berlangsung.

\section{Hasil Evaluasi Siklus II}

Setelah melakukan kegiatan pendekatan sebanyak tiga kali pertemuan selama dua minggu untuk menjelaskan materi terkait dengan membuat dan menentukan suku ke-n dari barisan geometri dan pertemuan ke dua untuk menyampaian materi tentang menentukan jumlah suku ke-n dari deret geometri dan pertemuan selanjutnya tentang menentukan jumlah tak hingga suatu deret geomerti dan melakukan evaluasi untuk mengetahui kemampuan daya tangkap selama pembelajaran. Evaluasi berlangsung selama 2 jam pelajaran $(2 \times 45$ menit). Bentuk soal evaluasi adalah essay sebayak 5 butir soal untuk dikerjakan secara individu. Masingmasing siswa mendapatkan satu lembar soal. Jawaban siswa kemudian diperiksa dengan skor maksimal 100 jika semua jawaban siswa benar dan skor 0 jika siswa tdak menjawab sama sekali, melalui hail evaluasi belajar nilai rata-rata siswa dan ketuntasan belajar siswa dapat terlihat pada Tabel.

\section{TABEL 4}

HASIL EVALUASI BELAJAR SISWA KELAS VII.C

\begin{tabular}{cll}
\hline No & \multicolumn{1}{c}{ Aspek yang Diukur } & Keterangan \\
\hline 1. & $\begin{array}{l}\text { Jumlah siswa yang ikut } \\
\text { evaluasi }\end{array}$ & 30 \\
\hline 2. & $\begin{array}{l}\text { Jumlah siswa yang tuntas } \\
\text { (siswa yang mencapai nilai }\end{array}$ & \\
60 atau lebih) & 28 \\
\hline 3. & $\begin{array}{l}\text { Jumlah siswa yang tidak } \\
\text { tuntas (siswa yang nilainya } \\
\text { kurang dari 60) }\end{array}$ \\
\hline 4. & Persentase ketuntasan & $93,3 \%$ \\
\hline 5. & Jumlah skor keseluruhan & 2540 \\
\hline 6. & Nilai rata-rata siswa & 81,93 \\
\hline 7. & Kategori & Tuntas \\
\hline
\end{tabular}


Berdasarkan hasil analisis pada Tabel 4 di atas terlihat bahwa ketuntasan belajar secara klasikal sudah mencapai 93,3\% dan penggolongan aktifitas belajar siswa pada pertemuan petama, kedua dan ketiga dengan katogori sangat aktif. Dari tabel di atas dapat terlahat bahwa jumlah siswa yang tuntas yaitu 28 orang dari 30 orang yang ikut melaksanakan evaluasi dan 1 orang tanpa keterangan. Prosentase ketuntasannya menunjukkan peningkatan dari siklus -siklus sebelumnya.

\section{Refleksi Siklus II}

Persantase ketuntasan belajar mengajar pada siklus pertama mencapai $64,5 \%$ ini menunjukkan bahwa ketuntasan dilihat dari hasil evaluasi pada siklus I masih belum mencapai hasil yang diharapkan, sedangkan pada siklus II segala permasalahan yang muncul pada siklus I dapat teratasi pada siklus II dengan prosentasi secara klasikal telah mencapai target 93,3\%siswa tuntas secara klasikal. Dengan demikian proses belajar mengajar dengan menggunakan penerapan metode brain storming lebih efektif digunakan dalam meningkatkan hasil belajar siswa dalam materi barisan dan deret kelas XI APK 1 Semester 1 SMKN 4 Mataram.

Selanjutnya, berdasarkan hasil analisis data tiaptiap siklus, terlihat bahwa hasil dari siklus ke siklus mengalami suatu peningkatan. Pada siklus pertama yang mengikuti evaluasi sebanyak 31 siswa, Jumlah siswa yang tuntas yang mencapai nilai 75 atau lebih sebanyak 20 siswa, sedangkan jumlah siswa yang mendapat nilai kurang dari 75 atau tidak tuntas sebanyak 11 siswa. Hal ini menunjukkan bahwa jumlah ketercapaian siswa sebanyak 25,95 yang diperoleh dari jumlah keseluruhan skor siswa. Untuk mengetahui jumlah rata-rata nilai belajar siswa yang diperoleh dari jumlah ketercapaian dibagi dengan jumlah keseluruhan siswa yang nilai rata-rata siswa sebesar 83,7. Untuk mengetahui persentase ketuntasan jumlah siswa yang tuntas sebanyak 20 siswa di bagi dengan jumlah keseluruhan siswa, untuk memperoleh hasil ketunutasan hasil belajar siswa maka yang digunakan adalah sesuai dengan rumus yang hasil prosentase ketuntasan sebanyak $64,5 \%$, Ini berarti ketuntasan belajar siswa belum tercapai dengan kata lain belum tuntas secara klasikal sesuai dengan ketuntasan belajar menurut standar sebanyak 85\% yang telah ditetapkan. Hal ini disebabkan karena kurangnya kesiapan siswa dalam mengikuti proses belajar dengan menggunakan penerapan metode brain storming, antusias siswa dalam pendekatan masih kurang karena masih banyak siswa yang terpengaruh situasi dalam kelas, saat diskusi masih banyak siswa yang belum mau mengeluarkan pendapat dan menanggapi pendapat dari temannya dan siswa belum bisa memebuat kesimpulan dari hasil diskusi sehingga tidak menemukan masalah baru dalam hasil diskusi, sehinnga tingkat penyerapan siswa terhadap materi yang diberikan belum optimal, akibatnya keaktifan dalam belajar tidak tercapai.

Hasil ini belum mencapai ketuntasan belajar siswa secara klasikal yang sesuai dengan standar yang menunjukkan $85 \%$ atau lebih dari kategori aktivitas belajar siswa aktif. Menurut hasil diskusi peneliti dengan observer dan setelah dilakukan refleksi, hal ini disebabkan kurangnya bimbingan dan pengarahan guru secara merata kepada siswa baik secara kelompok maupun individu pada saat mengerjakan soal-soal latihan dan lembar kerja siswa (LKS) siswa tidak terlalu memahami pelaksanaan dan langkah-langkah metode brain storming sehingga ketuntasan belajar siswa belum mencapai standar yaitu 85\%.Untuk mengatasi hal tersebut, khusus kepada siswa kelas XI APK 1 yang belum mencapai ketuntasan, peneliti memberikan tugas tmabahan dalam bentuk tindakan khusus dan bimbimgan mengenai cara-cara menyelesaikan soalsoal latihan yang belum dikuasai.

Karena ketuntasan belajar pada siklus I belum tercapai, maka kegiatan tindakan dilanjutkan kesiklus II dengan perbaikan seperti yang disarankan oleh observer, disamping itu juga melakukan pendekatan dan bimbingan khusus, pemberian tugas terbimbing pada saat siswa melakukan latihan. Berdasarkan hal tersebut maka siswa tidak bisa menjawab soal di karenakan siswa belum bisa menyerap materi terkait dengan materibarisan dan deret yang telah diajarkan. Untuk mengatasi banyaknya kekurangan selama pelaksanaan siklus I guru melakukan suatu perbaikan dalam pendekatan pada siswa berikutnya dan meningkatkan hal-hal yang dianggap kurang. Untuk itu guru berupaya meningkatkan ketertiban siswa dan membangkitkan respon siswa dalam proses pendekatan sesuai dengan repleksi pada siklus I, maka pada siklus II dilakukan tindakan yang merupakan suatu penyempurnaan dan perbaikan terhadap kekurangan-kekurangan yang muncul pada siklus I.

Berdasarkan hasil analisis pada siklus ke II menunjukan bahwa nilai rata-rata sebesar 81,9 dengan prosentase ketuntasan belajar siswa sebesar 93,3\%. Ini berarti ketuntasan belajar siswa telah tuntas secara klasikal sesuai dengan ketuntasan yang telah ditetapkan. Hal ini disebabkan karena persiapan siswa dalam mengikuti proses pembelajaran pendekatan dengan menggunakan penerapan metode brain storming sudah sangat baik, suasana pendekatan berjalan dengan baik, perhatian siswa sudah mulai terfokus, saat diskusi siswa sudah banyak yang mau mengeluarkan pendapat, menanggapi pendapat dari temennya, sehingga siswa bisa menemukan masalah baru dalam didkusi dan siswa sudah mulai bisa membuat kesimpulan dari hasil diskusi. Karena tujuan dari penelitian sudah 
tercapai dan kegiatan pendekatan sesuai dengan rencana dan harapan, maka siklus penelitian diakhiri.

Penerapan metode brain storming bisa meningkatkan hasil belajar siswa karena dengan penerapan metode tersebut siswa mempunyai kesempatan untuk mengeluarkan ide-ide atau gagasan sehingga bisa menemukan masalah baru baik dalam diskusi kelompok maupun secara indipidu. Dari pengalaman yang diperolah peneliti di lapangan selama melakukan penelitian, dengan menerapkan metode brain storming dalam meningkatkan hasil belajar siswa pada materisegitiga dengan melibtkan siswa berperan aktif dan melibatkan segenap kemampuan yang dimiliki siswa sehingga dapat meningkatkan hasil belajar siswa. Hal ini sesuai dengan teori yang mengatakan bahwa bila anak belajar matematika terpisah dari pengalaman mereka sehari-hari maka akan cepat lupa dan tidak dapat mengaplikasikan matematika.Guru dalam pendekatannya dikelas tidak mengaitkan dengan skema yang telah dimiliki oleh siswa dan siswa kurang diberikan kesempatan untuk menemukan kembali dan mengkonstruksikan sendiri ide-ide matematika. Mengaitkan pengalaman kehidupan nyata anak dengan ide-ide matematika dalam pendekatan di kelas penting dilakukan agar pendekatan bermakna.

Penerapan metode brain storming sesuai dengan langkah-langkah yaitu memberikan kesempatan kepada siswa kelas XI APK 1 semester I untuk menemukan kembali materi yang ada dalam pelajaran matematika terkait dengan materi barisan dan deret yang diberikan oleh guru berdasarkan masalah yang berupa soal-soal yang berbentuk essay. Dengan penerapan metode brain storming sangat memebantu siswa dalam memecahkan masalah yang terkait dengan masalah kehidupan seharihari.Sedangkan dilihat dari kongkritnya dapat membantu siswa menggunakan cara-cara informal yang merupakan produksi siswa dalam memegang peranan penting dalam menemukan kembali dan mengkruktusikan konsep matematika. Hal ini berarti informasi yang diberikan siswa telah dikaitkan dengan skema (jaringan representasi anak). Melalui intraksi kelas keterkaitan skema anak menjadi lebih kuat sehingga pengertian siswa tentang konsep yang mereka konstruksi sendiri menjadi kuat. Karena itu, perubahan persepsi guru tentang mengajar perlu dilakukan bila ingin mengimplementasikan penerapan metode brain storming. Dengan demikian, penerapan metode brain storming akan mempunyai konstribusi yang sangat tinggi dengan pengertian siswa. Sedangkan guru hanya sebagai fasilitator dan maotifator, sehingga memerlukan paradigma yang berbeda tentang bagaimana siswa belajar, bagaimana guru mengajar, dan apa yang dipelajari oleh siswa dengan paradigma pendekatan matimatika seperti memahami materi barisan dan deret, memahami cara penyelesaian soal-soal barisan dan deret selama ini. Karena itu, perubahan persepsi guru tentang mengajar perlu dilakukan bila ingin mengimplementasikan penerapan metode brain storming (MBS). Hal di atas sesuai dengan keutamaan penerapan dengan masalah yang mendasar dalam pendidikan diindonesia adalah masih rendahnya perestasi siawa dalam belajar matimatika. Beberapa laporan menyebutkan faktor penyebabnya yaitu: Kurangnya kualitas materi pendekatan, metode pengajaran yang mekanistik serta buruknya sistem penilain. Salah satu penerapan pembelajaran yang menjanjikan dapat mengurangi masalah tersebut adalah penerapan metode brain storming (MBS). Hal ini menunjukan banwa hasil belajar siswa pada siklus II yaitu dengan nilai ketuntasan 90,3\% tuntas secara klasikal yang smenunjukkan bahwa penerapan metode brain storming dalam meningkatkan hasil belajar siswa MATERI barisan dan deret di kelas XI APK 1 smester 1 SMK Negeri 4 Mataram dapat meningkatkan hasil belajar siswa.

\section{SIMPULAN DAN SARAN}

Dari hasil penelitian dan pembahasan dapat diambil kesimpulan bahwa penerapan metode Brain Storming dapat meningkatkan hasil belajar matematika siswa. Metode brain storming tersebut diterapkan dengan cara melibatkan siswa secara aktif (diskusi dalam kelompok kecil) dengan memberikan masalah pada siswa sehingga siswa menaggapi permasalahan yang diberikan guru. Guru tidak boleh mengevaluasi tanggapan siswa, tugas guru disini hanya mengumpulkan tanggapan-tanggapan dari siswa dan bersama siswa menyimpulkan hasil diskusi. Menggunakan LKS sebagai perangkat pembelajaran. Hal ini dapat dilihat dari prosentase ketuntasan belajar secara klasikal yaitu $64,5 \%$ dengan nilai rata-rata 83,709 dari 31 orang siswa dengan rincian 20 siswa tuntas dan 11 orang siswa tidak tuntas dengan prosentase $35,4 \%$ pada siklus I, dan meningkat menjadi $93,3 \%$ dengan nilai rata-rata 81,9 pada siklus II dari 30 orang siswa dengan rincian 28 siswa tuntas dan 2 orang siswa tidak tuntas. Satu orang siswa dinyatakan tidak hadir (tanpa keterangan ) pada saat evaluasi siklus II. Sehingga prosentase siswa yang tidak tuntas 6,67\%.

Berdasarkan hasil penelitian tersebut, maka tim peneliti menyampaikan: (a) Kepada siswa diharapkan untuk menumbuhkan sikap dan kebiasaan-kebiasaan berlatih secara terus menerus dalam belajar Matematika khususnya dan pelajaran yang lain pada umumnya, karena latihan akan membangkitkan semangat untuk senantiasa mengingat apa yang telah diterima; (b) Kepada Guru Matematika agar senantiasa memberikan latihan dan bimbingan kepada siswa agar memperoleh hasil belajar yang maksimal; (c) Kepada Kepala sekolah agar memperhatikan fasilitas dan media yang dapat 
digunakan oleh guru agar dapat meningkatkan tujuan pemelajaran; (d) Selanjutnya pada peneliti yang ingin mengadakan penelitian dapat meneliti pembelajaran matematika dengan menggunakan metode Brain Storming pada materiyang berbeda.

\section{REFERENSI}

[1] Ahmadi dan Nur Uhbiyati. (2003). Ilmu Pendidikan. Jakarta: Rineka Cipta.

[2] Arikunto Suharsimi. (2007). Penelitian Tindakan Kelas. Bandung: CV. Yrama Widya.

[3] Bahurdin dan Esa Nur Wahyuni. (2008). Teory Belajar dan Pembelajaran. Jogjakarta: Ar-Ruzz Media.

[4] Dimmyati dan Mudjiono. (2013). Belajar dan Pembelajaran. Jakarta: Rineka Cipta.

[5] Djamarah. (2012). Hasil Belajar Dan Kompetensi Guru. Surabaya: Usaha Nasional.

[6] Ghony D. (2008). Penelitian Tindakan Kelas. Malang: UIN-Malang Press.

[7] Hamalik. (2009). Pendekatan Baru Strategi Belajar Mengajar Berdasarkan CBSA. Bandung: Sinar Baru Algensindo.

[8] M. Iqbal Hasan. (2002). Pokok-pokok Materi metodologi Penelitian dan Aplikasinya. Jakarta: Ghalia Indonesia.

[9] Roestiyah. (2012). Strategi Belajar Mengajar Jakarta: Rineka Cipta.

[10] Suryadana I Wayan. (2013). Penerapan Kooparatif GI Untuk Meningkatkan Aktifitas dan Hasil Passing Control Sepak Bola.

[11] IrawatiAgus. Dkk. (2008). Buku BSE Mahir Matematika Untuk SMK non Teknin Kelas XI.Jakarta: PT Galaxy Puspa Mega

[12] To'ali. (2008). Buku BSE Matematika SMK kelompok Penjualan dan Akutansi. Jakarta: Pusat Perbukuan Departemen Pendidikan Nasional 